\title{
STATUS OSÓB UJAWNIAJAZCYCH NIEPRAWIDŁOWOŚCI W MIEJSCU PRACY W REPUBLICE SŁOWACKIEJ I JEGO EWOLUCJA Z PERSPEKTYWY PRZEPISÓW USTAWY Z DNIA 16 PAŹDZIERNIKA 2014 ROKU
}

\begin{abstract}
Status of People who Disclose Wrongdoing or Malpractices in the Workplace in the Slovak Republic and Its Evolution Including the Act Adopted on $16^{\text {th }}$ October 2014
\end{abstract}

The article is focused on origins and implementation of the Slovak Act on whistleblowers protection adopted in 2014 and its practical consequences. Author analyses attitudes of the Slovak society towards reporting corruption and their evolution in the last four years. Key legal mechanisms of whistleblowers protection against reprisal were also presented.

Keywords: protection of whistleblowers, preventing corruption, discrimination against employees, whistleblowing law in Slovakia, social perception of whistleblowers.

\section{Streszczenie}

Artykuł poświęcony jest genezie i wdrażaniu słowackiej ustawy o ochronie pracowników zgłaszających nieprawidłowości przyjętej w 2014 roku oraz praktyce jej stosowania. Autor analizuje postawy słowackiego społeczeństwa wobec zgłaszania korupcji i ich ewolucję na przestrzeni ostatnich czterech lat. Przedstawione zostały też istotne, z perspektywy sygnalistów, ustawowe gwarancje ochrony przed odwetem.

Słowa kluczowe: ochrona sygnalistów, przeciwdziałanie korupcji, dyskryminacja pracowników, prawo o sygnalistach na Słowacji, społeczny odbiór sygnalistów. 


\section{Wprowadzenie}

Niniejszy artykuł został poświęcony procesowi wzmacniania ochrony prawnej tak zwanych sygnalistów (ang. whistleblowers) w Republice Słowackiej, genezie i przyjętych w słowackim prawodawstwie środkach mających zapewnić bezpieczeństwo osobom narażonym na represje z powodu informowania o nieprawidłowościach zaobserwowanych w miejscu pracy.

Uchwalona przez słowacką Radę Narodową Republiki Słowackiej ustawa z 16 października 2014 roku o niektórych sposobach zgłaszania działań przeciwko społeczeństwu oraz o zmianie niektórych innych ustaw (słow. Zakon zo 16. oktobra 2014 o niektórych opatreniach súvisiacich z oznamovanim protispoločenskej činnosti a o zmene a doplnení niektorých zákonov, dalej: Ustawa 307/2014) sprawiła, że Słowacja stała się dziewiątym w Europie państwem z osobną regulacją ustawową dedykowaną sygnalistom ${ }^{1}$. Nowe prawo weszło w życie 1 stycznia 2015 roku, z wyjątkiem przepisów nakładających na pracodawców obowiązek stworzenia w swoich organizacjach bezpiecznej możliwości zgłaszania nadużyć, na co otrzymali dodatkowe pół roku. Ustawa 307/2014 ma zabezpieczać prawa pracowników decydujących się w dobrej wierze poinformować o zachowaniach zagrażających interesowi publicznemu, i przy tym gwarantować, że nie staną się oni ofiarami działań odwetowych.

Geneza słowackiej Ustawy 307/2014, okoliczności jej wprowadzenia, zapisany w niej mechanizm ochrony, a także odbiór społeczny i praktyka stosowania przepisów to główne przedmioty analizy zawartej w niniejszym artykule. Wskazane zostaną najważniejsze przesłanki uchwalenia ustawy oraz wpływ nowego prawa na częstość zgłaszania nieprawidłowości i poczucie bezpieczeństwa sygnalistów.

W artykule starano się na przykładzie słowackiego przykładu regulacji whistleblowingu odpowiedzieć na pytania o: (1) znaczenie społeczno-kulturowych uwarunkowań dla rozwoju prawa o sygnalistach, (2) realne możliwości ochrony sygnalistów na podstawie obowiązującego prawa oraz (3) wpływ regulacji prawnych na zmianę postaw społecznych wobec sygnalistów i częstsze podejmowanie przez nich decyzji o ujawnianiu nadużyć.

Uchwalenie Ustawy 307/2014 na Słowacji, będącej wyjątkową regulacją, biorąc pod uwagę, że w sąsiedniej Polsce, a nawet jeszcze bardziej historycznie i kulturowo zbliżonej do Słowacji Republice Czeskiej² brakuje analogicznego aktu prawnego, pozwala przy puszczać, że na Słowacji: (1) poziom ochrony sygnalistów przed wejściem w życie nowego prawa był dalece niewystarczający; (2) była to regulacja wyczekiwana i pozytywnie przyjęta przez społeczeństwo; (3) wzrosła

1 Przed Słowacją na podobny krok zdecydowały się: Wielka Brytania (1998), Belgia (2013), Malta (2013), Irlandia (2014), a także inne państwa Europy Środkowo-Wschodniej: Rumunia (2004), Słowenia (2010), Węgry (2013) i Serbia (2014); za: Waszak, 2016.

2 Według czeskiej organizacji Fundusz Antykorupcyjny (Nadačni fond proti korupci - NFPK), słowacki system ochrony sygnalistów powinien też wskazywać kierunek zmian w Czechach, za: Are whistleblowers..., 2014. 
liczba możliwości bezpiecznego raportowania nieprawidłowości i poziom ochrony zgłaszających.

W celu zweryfikowania niniejszych hipotez po pierwsze, zostanie przeprowadzona analiza źródeł wtórnych opisujących postawy wobec sygnalistów oraz skuteczność ich ochrony przez obowiązujące prawo. Po drugie, zostanie zastosowana metoda analizy i porównania danych pierwotnych pochodzących z badań społecznych z różnych lat na temat społecznego odbioru problemu korupcji i jej raportowania. Po trzecie, zostaną zbadane najważniejsze przepisy ustawowe istotnych pod względem zmiany statusu sygnalistów na Słowacji.

Ponieważ ustawa o ochronie sygnalistów funkcjonuje na Słowacji dopiero od 2015 roku, oznacza to, że literatury na ten temat wciąż powstało niewiele. Analizując przepisy Ustawy 307/2014, oprócz tekstu źródłowego korzystałem z dostępnych w języku angielskim opracowań słowackich autorów, w tym w szczególności z artykułu Daniela Krošláka i Andrei Olšovskiej oraz informacji zebranych przez Transparency International Slovensko (TIS). Społeczne uwarunkowania raportowania nieprawidłowości na Słowacji opisywałem przez pryzmat cyklicznego badania percepcji korupcji TI pod nazwą Światowy Barometr Korupcji (Global Corruption Barometer, GCB), które w 2013 i 2016 roku było realizowane na Słowacji, a także z uwzględnieniem wyników Specjalnych Eurobarometrów poświęconych korupcji w państwach Unii Europejskiej (Special Eurobarometer, SE).

\section{Definicje i rozwój prawa dotyczącego sygnalistów na świecie}

Transparency International (TI), pozarządowa organizacja, która od lat działa na rzecz wzmocnienia praw sygnalistów na świecie, pojęcie whistleblowing definiuje jako „ujawnianie korupcji, nielegalnych, oszukańczych lub niebezpiecznych działań popełnianych w lub poprzez organizacje sektora prywatnego i publicznego, które budzą obawę lub stwarzają zagrożenie dla interesu publicznego - do jednostek i ciał zdolnych podjać działania zaradcze w tej sprawie" [International Principles..., 2013: 4]. Z kolei Rada Europy, jedna z organizacji międzynarodowych formułująca swoje rekomendacje dotyczące standardów ochrony sygnalistów, pojęcia whistleblowers używa na określenie osób ,zgłaszających lub ujawniających informacje o zagrożeniach lub szkodach dla interesu publicznego w miejscu pracy, bez względu na to, czy pracują w sektorze prywatnym, czy publicznym" [Rada Europy, 2014: 6]. Sygnaliści zatem to osoby z wewnątrz organizacji (ang. insiders), którym ze względu na ich działania w obronie interesu publicznego i narażanie się z tego tytułu na szkody zdrowotne, materialne i moralne $\mathrm{w}$ wielu państwach na podstawie odrębnych ustaw przyznaje się specjalną ochronę. Procedury zapewniające ochronę sygnalistom wykorzystywane są jako środek przeciwdziałania korupcji, ale informacje przez nich dostarczane odnoszą się do dużo szerszego spektrum nieprawidłowości. W sektorze prywatnym poprzez wewnętrzne mechanizmy zgłaszania nadużyć pracownicy ujawniają 
m.in. zagrożenia dla bezpieczeństwa pracy i zdrowia pracowników, oszustwa finansowe, przypadki łamania praw człowieka, mobbing, przestępstwa przeciwko ochronie danych osobowych, niedozwolone praktyki monopolowe czy ryzyka dla środowiska naturalnego [Committing to Effective Whistleblower Protection..., 2016].

Po raz pierwszy dedykowaną sygnalistom ochronę prawną w postaci osobnej ustawy wprowadzono w Stanach Zjednoczonych, tam również narodził się termin whistleblowing. W 1989 roku Kongres przyjął Ustawę o ochronie sygnalistów, która objęła działaniem pracowników administracji federalnej i wyszczególnionych przedsiębiorstw państwowych. Podobne regulacje szybko rozpowszechniły się w krajach stosujących prawo precedensowe (ang. common law), takich jak Kanada, Nowa Zelandia czy Australia, której pierwszy stan South Australia wprowadził prawodawstwo o sygnalistach już w 1993 roku. W Europie także kraj z kręgu kultury anglosaskiej - Wielka Brytania - przyjmując Public Interest Disclosure Act w 1998 roku, był pionierem w tej materii na swoim kontynencie. W XXI wieku gwałtownie wzrosła liczba krajów, i to głównie z Europy, takich jak Holandia, Francja, Szwecja czy Włochy, które zdecydowały się przyznać sygnalistom ustawową ochronę. Do chwili obecnej powstało już kilkanaście takich ustaw obowiązujących na świecie, m.in. w Republice Południowej Afryki, Korei Południowej, Japonii i Indiach.

Nie bez znaczenia jest tutaj presja wywierana na państwa ze strony organizacji międzynarodowych, takich jak Organizacja Współpracy Gospodarczej i Rozwoju (OECD), Rada Europy czy Organizacja Narodów Zjednoczonych (ONZ). Wynika ona z konkretnych aktów prawa międzynarodowego, których państwa sygnatariusze, w tym Republika Słowacka, zobowiązali się przestrzegać. Cywilnoprawna Konwencja o Korupcji nakłada obowiązek ochrony przed nieuzasadnionymi sankcjami pracowników, którzy w dobrej wierze zgłaszają odpowiednim organom swoje podejrzenia korupcji ${ }^{3}$. Podobnie Konwencja Narodów Zjednoczonych Przeciwko Korupcji zaleca wdrożenie odpowiednich środków dla zapewnienia ochrony osobom zgłaszającym na podstawie racjonalnych przesłanek przestępstwa korupcyjne ${ }^{4}$. Przed Słowacją stał też obowiązek uwzględnienia wytycznych OECD wynikających z Konwencji o zwalczaniu przekupstwa zagranicznych funkcjonariuszy publicznych w międzynarodowych transakcjach handlowych z 1997 roku oraz Rekomendacji w sprawie dalszego zwalczania przekupstwa w międzynarodowych transakcjach handlowych z 2009 roku, zawierających zalecenie stworzenia kanałów informowania o podejrzeniach przekupstwa zagranicznych funkcjonariuszy publicznych oraz środków ochrony osób je zgłaszających ${ }^{5}$. W ostatnim raporcie

${ }^{3}$ Cywilnoprawna Konwencja o Korupcji Rady Europy sporządzona w Strasburgu dnia 4 listopada 1999 r., Artykuł 9.

${ }^{4}$ Konwencja Narodów Zjednoczonych Przeciwko Korupcji, przyjęta przez Zgromadzenie Ogólne Narodów Zjednoczonych dnia 31 października 2003 r., Artykuł 33.

${ }^{5}$ Rekomendacje Rady OECD w sprawie dalszego zwalczania przekupstwa zagranicznych funkcjonariuszy publicznych w międzynarodowych transakcjach handlowych z dnia 26 listopada 2009 r., Rekomendacja IX. 
monitorującym wdrażanie kryteriów OECD na Słowacji odnotowano przyjęcie w tym zakresie nowego prawa (OECD, 2014).

W instytucjach Unii Europejskiej widać coraz większą chęć wprowadzenia horyzontalnej regulacji standardów ochrony sygnalistów i zharmonizowania dotychczas istniejących przepisów we wszystkich krajach członkowskich. Do tej pory ochrona pracowników informujących o nieprawidłowościach w prawie unijnym wprowadzana była sektorowo, to znaczy zostały wyznaczone prawne ramy ich ochrony w sektorze finansowym ${ }^{6}$, prawo do sygnalizowania $\mathrm{w}$ interesie publicznym zostało też zapisane $\mathrm{w}$ dyrektywach o ochronie tajemnicy przedsiębiorstwa ${ }^{7}$ i o przeciwdziałaniu praniu brudnych pieniędzy lub finansowaniu terroryzmu ${ }^{8}$. Jednakże istnieje coraz większa presja, wywierana m.in. przez organizacje społeczne i związki zawodowe na Komisję Europejską, wyrażona też w rezolucjach Parlamentu Europejskiego' ${ }^{9}$ na przyjęcie kompleksowej regulacji dotyczącej ochrony sygnalistów obowiązującej dla wszystkich państw członkowskich.

\section{Społeczeństwo słowackie wobec zgłaszania nadużyć}

Słowacja należy do krajów byłego bloku wschodniego, gdzie wciąż żywe jest wspomnienie okresu komunistycznego, a informowanie o podejrzeniach nieprawidłowości budzi złe skojarzenia z przeszłości, związane donoszeniem do StB (czes. Státní bezpečnost), czyli czechosłowackiego aparatu bezpieczeństwa.

Badania społeczne realizowane na zlecenie TIS przed 2016 rokiem kilkukrotnie pokazały, że obywatele gotowi zgłosić policji próbę wyłudzenia od nich łapówki lub przyjmowanie łapówek przez inną osobę stanowią około $20 \%$ słowackiego społeczeństwa (FOCUS/TIS, 2016). Wynik ten może świadczyć o niezwykle niskim zaufaniu do instytucji ochrony prawnej na Słowacji, o społecznej akceptacji dla zachowań korupcyjnych lub o braku poczucia moralnej i prawnej odpowiedzialności, które spoczywa na świadku przestępstwa. Każde z tych hipotetycznych

${ }^{6}$ Zob. Dyrektywa wykonawcza Komisji (UE) 2015/2392 z dnia 17 grudnia 2015 r. w sprawie rozporządzenia Parlamentu Europejskiego i Rady (UE) nr 596/2014 w odniesieniu do zgłaszania właściwym organom rzeczywistych lub potencjalnych naruszeń tego rozporządzenia.

7 Zob. Dyrektywa Parlamentu Europejskiego i Rady (UE) 2016/943 z dnia 8 czerwca 2016 r. w sprawie ochrony niejawnego know-how i niejawnych informacji handlowych (tajemnic przedsiębiorstwa) przed ich bezprawnym pozyskiwaniem, wykorzystywaniem i ujawnieniem.

${ }^{8}$ Zob. Dyrektywa Parlamentu Europejskiego i Rady (UE) 2015/849 z dnia 20 maja 2015 r. w sprawie zapobiegania wykorzystywaniu systemu finansowego do prania pieniędzy lub finansowania terroryzmu, zmieniająca rozporządzenie Parlamentu Europejskiego i Rady (UE) nr 648/2012 i uchylająca dyrektywę Parlamentu Europejskiego i Rady 2005/60/WE oraz dyrektywę Komisji 2006/70/WE.

${ }^{9}$ Zob. Rezolucja Parlamentu Europejskiego z dnia 14 lutego 2017 r. Rola demaskatorów w ochronie interesów finansowych UE (2016/2055(INI)); Rezolucja Parlamentu Europejskiego z dnia 24 października 2017 r. w sprawie uzasadnionych środków ochrony sygnalistów działających $\mathrm{w}$ interesie publicznym podczas ujawniania poufnych informacji posiadanych przez przedsiębiorstwa i organy publiczne (2016/2224(INI)). 
uzasadnień znajduje mocne dowody. Niska gotowość do zgłaszania korupcji jest tym bardziej znacząca, że zgodnie ze słowackim kodeksem karnym każda osoba, która ma uzasadnione podejrzenie o popełnieniu jednego z przestępstw korupcyjnych i nie zgłosi go niezwłocznie do odpowiedniego organu lub na policję, teoretycznie podlega karze do trzech lat więzienia (Providing an alternative..., 2012).

Niemal 60\% respondentów przebadanych na Słowacji w 2013 roku odpowiedziało, że zwykły człowiek nie jest w stanie nic zdziałać w walce z korupcją (GCB, 2016). Cykliczne badania korupcji prowadzone w ramach Eurobarometru potwierdzają, iż ujawnianie zachowań korupcyjnych należy do rzadkich postaw w słowackim społeczeństwie. Słowacy, którzy przyznali, że w ostatnim roku doświadczali korupcji lub byli jej świadkami, pytani o to, czy gdziekolwiek zgłosili ten fakt, w zdecydowanej większości (96\%) zaprzeczyli (SE 397, 2014). Pytani o powody, dla których świadkowie korupcji decydują się jej nie ujawniać, wskazali trudności w udowodnieniu przestępstwa (45\%), przekonanie o ostatecznym uniknięciu kary przez osoby odpowiedzialne (39\%), brak ochrony osób raportujących korupcję (35\%) oraz świadomość, że mimo powszechnej wiedzy o korupcyjnych praktykach nikt na to nie reaguje (32\%) (SE 397, 2014). Jak wynika z tych danych, Słowacy dużo bardziej obawiają się odwetu otoczenia za poinformowanie o przestępstwie aniżeli kary grożącej za niezgłoszenie tego faktu na podstawie kodeksu karnego.

Głęboki sceptycyzm słowackiego społeczeństwa wobec sensu zgłaszania przestępstw korupcyjnych korespondował z opinią większości Słowaków, że korupcja stanowi jeden z poważniejszych problemów ich kraju, którego skala na dodatek w ostatnich latach wzrosła (SE 397, 2014). Słowacja należy też do krajów o największej społecznej akceptowalności praktyk korupcyjnych w Unii Europejskiej, gdzie świadczenie przysług (68\%), wręczanie prezentów (50\%) czy pieniędzy (29\%) w kontaktach z administracją publiczną jest postrzegane jako utrwalona norma zachowań (SE 397, 2014).

Wyzwaniem dla stosowania Ustawy 307/2014 było z jednej strony przyzwyczajenie Słowaków do korupcji w życiu publicznym i ich niechęć do reagowania, gdy stają się jej świadkami. $Z$ drugiej strony prawo to odpowiadało na poważny problem społeczny i dawało nadzieję, że społeczeństwo zacznie bardziej pozytywnie odnosić się do sygnalistów a ujawnianie nieprawidłowości w interesie publicznym będzie powszechniejsze.

\section{Stan ochrony prawnej sygnalistów przed 2014 rokiem i procedowanie nowego prawa}

Przez długi czas Słowacja nie realizowała swoich zobowiązań dotyczących ochrony sygnalistów wobec międzynarodowych organizacji. Jeszcze w 2013 roku TI oceniła Słowację jako kraj, w którym brakuje jakichkolwiek gwarancji ochrony sygnalistów albo są one szczątkowe [Whistleblowing in Europe..., 2013]. Podobnie surowa ocena słowackiego stanu prawnego znalazła się $\mathrm{w}$ raporcie 
antykorupcyjnym Komisji Europejskiej [Komisja Europejska, 2014]. W obu dokumentach załączono uwagę, że jedynym dostrzegalnym elementem ochrony sygnalistów obejmującym osoby pracujące w prywatnym sektorze jest zawarty w rozdziale 13 kodeksu pracy zakaz arbitralnego zwalniania lub dyskryminacji pracowników, który stanowi podstawę do dochodzenia praw osób niesprawiedliwie potraktowanych przez pracodawcę przed sądem. Wśród wielu zakazanych rodzajów dyskryminacji nie znajdował się jednak ten związany z odwetem za ujawnienie nieprawidłowości. Z kodeksu pracy wywodzi się też przepis zabraniający stosowania sankcji wobec pracowników wnioskujących o wszczęcie postępowania karnego wobec pracodawcy lub innego pracownika, składających skargę na ich działania lub wchodzących w spory sądowe mające związek z miejscem pracy [Whistleblowing in Europe..., 2013]. Ustawa 307/2014 dodała do tego katalogu także przypadek ujawnienia nieprawidłowości przez pracowników.

Zdaniem TI, poza prawem pracy trudno było doszukiwać się innych prawnych źródeł ochrony sygnalistów, a jedyną realną możliwością otrzymania pomocy przez sygnalistów była działalność Państwowego Centrum Praw Człowieka oraz organizacji pozarządowych (TI, 2012). Sektor pozarządowy promował wsparcie dla idei ochrony sygnalistów także przez przyznawaną od 2008 roku przez organizacje Aliancia Fair-play i Via Iuris nagrodę Białej Wrony dla osób, które wykazały się wyjątkową odwagą i poświęceniem w obronie dobra wspólnego [Cuprik, 2016].

Uchwalenie Ustawy 307/2014 poprzedzone zostało kilkoma latami negocjacji jej kształtu z partnerami społecznymi i przygotowywania politycznego gruntu pod nowe prawo. W przyjętej w 2012 roku deklaracji programowej rządu Roberta Fico na lata 2012-2016 znalazła się zapowiedź wzmocnienia polityki antykorupcyjnej poprzez zagwarantowanie ochrony prawnej osobom raportującym korupcję [Krošlák, Olšovska, 2015]. Projekt ustawy zaczął być procedowany pod presją organizacji społeczeństwa obywatelskiego i oczekiwań elektoratu, który w zdecydowanej większości (79\%) uważał dotychczas podejmowane przez rząd wysiłki na rzecz zmniejszenia korupcji za nieskuteczne (SE 374, 2012).

Najpierw próby wdrażania wewnętrznych ścieżek raportowania korupcji w sektorze publicznym podjęto wewnątrz ministerstw. Kancelaria Rządu Republiki Słowackiej otworzyła w 2011 roku, jako pierwszy urząd centralny, wewnętrzną linię raportowania przypadków korupcji, a w ślad za tym podobne procedury wdrożyły słowackie ministerstwa. Działania te nie przyniosły jednak spodziewanych rezultatów, bowiem w latach 2011-2013 w urzędach administracji rządowej, z wyjątkiem Kancelarii Premiera, Ministerstwa Spraw Zagranicznych i Ministerstwa Obrony, nie zarejestrowano ani jednego przypadku whistleblowingu [Whistleblowing in Europe..., 2013]. Zdaniem ekspertów za nieskuteczność kanałów informowania odpowiedzialna była niska wiarygodność zarządzających nimi instytucji i brak przekonania, że potrafią one odpowiedzialnie i skutecznie zająć się zgłoszeniami [Krošlák, Olšovska, 2015]. Ci sami eksperci negatywnie ocenili proces wdrożenia kanałów raportowania, o możliwości skorzystania z których pracownicy nie zostali odpowiednio poinformowani i przeszkoleni, same procedury zaś nie zostały ujęte w wewnętrznych regulaminach pracy. Nieskuteczność przyjętych rozwiązań była też konsekwencją ówczesnego braku jakiejkolwiek ustawowej ochrony 
funkcjonariuszy publicznych ujawniających przypadki korupcji, co odnotowało ONZ (UNODC, 2013).

Działania na rzecz przyjęcia słowackiej ustawy o sygnalistach od początku wspierała TIS, natomiast sam proces jej przygotowania nie wzbudził większego zainteresowania opinii publicznej ani innych potencjalnie ważnych aktorów społecznych, takich jak związki zawodowe czy organizacje pracodawców. W skład grupy roboczej przy Ministerstwie Spraw Wewnętrznych pracującej nad projektem ustawy od lutego 2012 weszli, obok urzędników MSW, przedstawiciele Ministerstwa Sprawiedliwości, organizacje pozarządowe, eksperci prawni i funkcjonariusze policji. W głosowaniu w parlamencie prawo o sygnalistach poparli zarówno politycy partii rządzącej, jak i opozycji. Ustawa 307/2014 okazała się politycznie użyteczna dla partii rządzącej SMER, gdyż dzięki jej uchwaleniu rząd słowacki mógł uwiarygodnić i zademonstrować swoje starania na rzecz walki z korupcją, co zostało wykorzystane w kampanii przed wyborami parlamentarnymi w 2016 roku [Waszak, 2016].

\section{Ochrona sygnalistów w świetle ustawy z 20 I 4 roku}

\section{I. Zakres ochrony i działań podlegających zgłoszeniu}

Ustawa z 16 października 2014 roku wprowadza zasady ochrony dedykowane dwóm grupom - pracownikom sygnalizującym nieprawidłowości oraz świadkom przestępstw. W myśl słowackich przepisów, sygnalistą jest osoba fizyczna, która w związku z wykonywanymi przez siebie czynnościami służbowymi zgłasza w dobrej wierze „poważne działania przeciwko społeczeństwu” do właściwego organu. Zakres podmiotowy ustawy obejmuje pracowników związanych stosunkiem pracy stałym lub tymczasowym, w tym urzędników i przedstawicieli służb mundurowych, z wyłączeniem operacji wojskowych i wywiadowczych.

Pojęcie ,poważnych działań przeciwko społeczeństwu” (dalej: nieprawidłowości) zostało zdefiniowane w artykule 2, punkt 1, podpunkt C Ustawy 307/2014 i oznacza niedozwolone prawem postępowanie, które:

- jest jednym z przestępstw wymierzonych przeciwko finansowym interesom wspólnoty europejskiej, przestępstwem związanym z realizacją zamówień i aukcji publicznych, przestępstwem popełnianym przez urzędników państwowych lub przestępstwem korupcyjnym, zdefiniowanym w odrębnych przepisach kodeksu karnego;

- lub przestępstwem zagrożonym na podstawie przepisów kodeksu karnego karą pozbawienia wolności, której maksymalna wysokość wynosi więcej niż trzy lata;

- lub wykroczeniem administracyjnym karanym grzywną w maksymalnej wysokości wynoszącej co najmniej 50 tysięcy euro.

Działanie w dobrej wierze Ustawa 307/2014 definiuje jako postępowanie osoby, która jest przekonana, w świetle znanych jej okoliczności oraz dostępnej w danym 
momencie wiedzy, że informacje przez nią przekazywane są prawdziwe. Wątpliwości dotyczące tego, czy dobra wiara zaistniała w określonych przypadku, interpretuje się na korzyść sygnalisty. Jeśli natomiast zostanie udowodnione, że pracownik w sposób świadomy zafałszował zgłoszoną informację, to pozbawia się go ochrony. Ustawa dopuszcza anonimowe zgłaszanie nieprawidłowości.

\subsection{Ochrona prewencyjna}

Ewenement Ustawy 307/2014 polega m.in. na tym, że gwarantuje ona pracownikom zgłaszającym nieprawidłowości ochronę prawną przed krzywdzącymi działaniami pracodawcy, które mogą być podjęte wobec nich w przyszłości. Sygnalista sam może wystosować $\mathrm{w}$ formie pisemnej lub ustnej prośbę o ochronę do prokuratury, sądu lub odpowiedniego organu administracyjnego, w zależności od charakteru zgłoszonej nieprawidłowości i prowadzonego postępowania w ramach procedury karnej lub administracyjnej. Jeśli organ, do którego skierowano taką prośbę, uzna osobę ją zgłaszającą za sygnalistę, to bezzwłocznie zawiadamia inspekcję pracy, pracodawcę i wnioskodawcę o chęci przyznania mu ochrony prawnej. Od tego momentu pracodawca może podejmować dopuszczalne prawem działania lub uznaniowe decyzje niekorzystne dla sygnalisty bez jego zgody tylko za wcześniejszą aprobatą inspekcji pracy. Inspekcja jest zobowiązana wydać swoją decyzję najpóźniej w ciągu trzydziestu dni. Może się ona okazać pozytywna dla pracodawcy tylko i wyłącznie wtedy, gdy zostanie udowodnione, że nie zachodzi bezpośredni związek między decyzją pracodawcy a zgłoszeniem sygnalisty. Istnieje też możliwość odwołania się pracodawcy.

\subsection{Ochrona następcza}

Na drodze Ustawy 307/2014 wprowadzono procedurę ochrony następczej, przyznawanej po tym, jak negatywna decyzja pracodawcy wobec sygnalisty zapadła. Oznacza ona możliwość zawieszenia decyzji pracodawcy krzywdzącej osobę, która ujawniła pomniejsze nadużycia (np. nadużywanie uprawnień, konflikt interesów, złe gospodarowanie zasobami organizacji) poprzez wewnętrzny system zgłaszania nieprawidłowości lub poza nim, jeżeli nie został on poprawnie wdrożony (Oznamovatel'ov korupcie..., 2015). Warunkiem jest złożenie przez poszkodowanego pracownika odpowiedniego wniosku do inspekcji pracy w ciągu siedmiu dni od momentu, w którym poznał niekorzystną dla siebie decyzję. Jeśli wniosek został złożony poprawnie, a pracownik miał uzasadnione podejrzenie świadczące o dokonaniu na nim odwetu za ujawnienie niewygodnej informacji, to inspekcja pracy bezzwłocznie zawiesza decyzję pracodawcy. Zawieszenie to ważne jest czternaście dni, w trakcie których sygnalista może złożyć wniosek do sądu o przyznanie tymczasowych środków ochrony i unieważnienie decyzji pracodawcy, o której to możliwości musi zostać przez inspekcję poinformowany. Jeżeli w tym czasie sygnalista zwróci się do sądu, to okres zawieszenia decyzji 
pracodawcy zostanie przedłużony do czasu wejścia w życie orzeczenia sądowego w tej sprawie.

Jeżeli osoba fizyczna lub prawna nie wypełnia swoich zobowiązań dotyczących współpracy z inspekcją pracy w zakresie ochrony pracowników zgłaszających informacje o nadużyciach, to może otrzymać karę 500 euro.

\subsection{Możliwości bezpiecznego zgłaszania nieprawidłowości poprzez wewnętrzne systemy}

Ustawa 307/2014 nakłada na każdego prywatnego pracodawcę zatrudniającego co najmniej pięćdziesiąt osób oraz na każdą instytucję publiczną obowiązek ustanawiania osobnych jednostek organizacyjnych lub wyznaczania odpowiedzialnych za przyjmowanie zgłoszeń pracowników/osób zatrudnionych z zewnątrz. Obsługujący systemy zgłaszania nieprawidłowości muszą działać w sposób bezstronny i niezależny, dlatego odpowiadają bezpośrednio tylko przed organem statutowym, nawet jeśli jest to doradca na kontrakcie.

Pracodawcy mają obowiązek przyjąć i zweryfikować każde zgłoszenie w ciągu dziewięćdziesięciu dni, który to czas może zostać wydłużony o kolejne trzydzieści dni. Jeśli zgłoszenie nie było anonimowe, to przyjmujący je ma obowiązek zachować w sekrecie dane sygnalisty. Pracodawca, wprowadzając system zgłaszania nieprawidłowości, powinien określić i skutecznie przedstawić swoim pracownikom:

- sposób zgłaszania informacji;

- procedurę weryfikacji informacji i odpowiedzialną za nią osobę;

- gwarancje poufności osoby zgłaszającej;

- prowadzenie rejestru zgłoszeń (pozyskane informacje powinny być przechowywane przez okres co najmniej trzech lat);

- sposób powiadamiania osoby zgłaszającej o wynikach weryfikacji;

- sposób procedowania danych osobowych zawartych w zgłoszeniu.

Jeśli pracodawca nie wypełnia obowiązku prowadzenia wewnętrznego systemu zgłaszania nieprawidłowości zgodnie z ustawowymi wytycznymi, to inspekcja pracy może nałożyć na niego karę do 20 tysięcy euro.

\subsection{Edukacja, pomoc prawna i nagrody finansowe}

Na podstawie Ustawy 307/2014 państwo ma obowiązek działać na rzecz zapobiegania nieprawidłowościom, m.in. poprzez prowadzenie edukacji antykorupcyjnej zawartej w szkolnym programie nauczania [Krošlák, Olšovska, 2015]. Słowackiemu Państwowemu Centrum Praw Człowieka powierzono zadanie propagowania wiedzy na temat możliwości zgłaszania nieprawidłowości, publikowania opinii, ekspertyz, orzeczeń i informacji odnoszących się do ujawniania informacji i przyznawanej na podstawie Ustawy 307/2014 ochrony. W tym zadaniu Centrum mają wspierać ministerstwa oraz inne instytucje publiczne. 
Sygnaliści są też uprawnieni do korzystania z bezpłatnego poradnictwa prawnego za pośrednictwem centrum pomocy prawnej podlegającego Ministerstwu Sprawiedliwości po wcześniejszym przesłaniu aplikacji [Cuprik, 2016].

Ponadto Ustawa 307/2014 daje możliwość przyznania nagrody dla sygnalisty, który przyczynił się do odkrycia przestępstwa w maksymalnej wysokości 50-krotności minimalnej pensji na Słowacji, czyli około 19 tysięcy euro. Sygnalista może po nią wystąpić do Ministerstwa Sprawiedliwości w ciągu sześciu miesięcy po tym, jak zapadnie prawomocny wyrok potwierdzający popełnienie przestępstwa lub winę skazanych za nieprawidłowości ujęte w zgłoszeniu sygnalisty.

\section{Ochrona sygnalistów po wejściu w życie Ustawy z 2014 roku}

\section{I. Pierwszy okres stosowania Ustawy}

Nowe obowiązki dla pracodawców przewidziane w Ustawie 307/2014 wprowadzane pod groźbą kar pieniężnych musiały doprowadzić do wzrostu liczby kanałów zgłaszania nieprawidłowości w miejscach pracy.

Jednakże, jak pokazały dane słowackiej inspekcji pracy, wykorzystanie zewnętrznych mechanizmów ochrony sygnalistów w pierwszych ośmiu miesiącach funkcjonowania Ustawy 307/2014 było znikome. W tym okresie nie trafiło do inspekcji ani jedno żądanie zawieszenia decyzji pracodawcy podjętej przeciw sygnaliście. Zaledwie siedmiu pracowników ujawniających nieprawidłowości policji, prokuraturze lub innym insty tucjom zostało objętych ochroną przez inspekcję pracy (TIS, 2015). Ewaluacja funkcjonowania Ustawy 307/2014 za rok 2016, zrealizowana przez słowackie Państwowe Centrum Praw Człowieka, pokazała, że w tym czasie inspektoraty pracy zarejestrowały trzydziestu dwóch sygnalistów, przy czym w przypadku ośmiu z nich doszło potem do wygaszenia przyznanej ochrony prawnej [Cenkner, 2017]. W raporcie centrum pomocy prawnej, udzielającego bezpłatnego poradnictwa osobom, których nie stać na profesjonalną poradę, za rok 2016 odnotowano jedynie dwie sprawy związane z sygnalistami na 5893 wszystkich wniesionych aplikacji [Výročná Správa 2016, 2017].

Jak wskazała TIS, opierając się na wynikach przeprowadzonych przez siebie badań metodą „,tajemniczego klienta”, problemy z wdrażaniem Ustawy 307/2014 w okresie I-VIII 2015 roku, były związane ze złym przygotowaniem inspekcji pracy do pełnienia swoich funkcji. To bardzo ważne ogniwo w słowackim systemie ochrony sygnalistów, do którego kompetencji należą: promocja nowego prawa, kontrola wdrażania systemów zgłaszania nieprawidłowości, nakładanie kar na pracodawców, zawieszanie decyzji podejmowanych przeciwko sygnalistom i obejmowanie ich ochroną prewencyjną. Tak znaczący zakres nowych zadań przypisanych inspekcji pracy nie szedł w parze ze zwiększeniem liczby inspektorów, dodatkowymi szkoleniami dla nich ani przyznaniem większych środków budżetowych tej instytucji [Waszak, 2016]. TIS zarzuciła inspekcji pracy w swoim 
raporcie nieumiejętne prowadzenie działań informacyjnych, ograniczonych do suchego komunikatu na stronie internetowej, bez odwołania do przykładów, publikowania przystępnych materiałów informacyjnych, organizacji szkoleń, tworzenia algorytmów postępowania. Odpowiedzi na pytania o poradę kierowane do inspekcji przez potencjalnych sygnalistów nie przychodziły w terminie i w większości nie identyfikowały problemu właściwie (TIS, 2015).

\subsection{Społeczne uwarunkowania korzystania z ochrony}

Zdaniem organizacji Aliancia Fair-play, przepisy Ustawy 307/2014 mogą pozostać martwe, jeżeli obywatele nie zaczną ufać pracy policji, sądom i prokuraturze [Cuprik, 2016]. Według nich, potrzebna jest systemowa zmiana, która stworzy bardziej przyjazne warunki dla ochrony sygnalistów niż dotychczas. W badaniach to właśnie sądy orzekające w sprawach korupcji wskazywane są jako winne temu, że problem ten jest tak nabrzmiały (41\%), po nich na równi obwinia się policję i prokuraturę (po 22\%) (FOCUS/TIS, 2017). Większość Słowaków uważa też, że sądownictwo jest skorumpowane i podatne na wpływy biznesu (Slovakia Corruption Report, 2015). Połowa osób skazanych na kary więzienia za przestępstwa korupcyjne ostatecznie ich nie odbywa, a w sprawach, w których oskarżani są wysocy przedstawiciele władz publicznych, rzadko zapadają wyroki na ich niekorzyść [Rédli, 2015].

Bodźcem do rozpoczęcia publicznej dyskusji o sile sprawczej sygnalistów na Słowacji stała się też sprawa Zuzanny Hlavkovej, młodej urzędniczki Ministerstwa Spraw Zagranicznych, która ujawniła celowe zawyżenie kosztów dwóch koncertów otwierających prezydencję Słowacji w Unii Europejskiej. Ponieważ ministerstwo sprzeciwiało się tym zarzutom i utrudniało śledztwo, Hlavkova zdecydowała się odejść z pracy [Terenzani, 2016]. W ostatnim badaniu TIS połowa respondentów przyznała, że sprawa marnotrastwa środków publicznych przy organizacji koncertów zorganizowanych przez Ministerstwo jest jej znana (FOCUS/TIS, 2017).

\subsection{Nowe prawo a zmiana opinii społecznej na temat sygnalizowania}

Już po wejściu w życie Ustawy 307/2014 TIS zleciło w 2016 i 2017 roku badania społeczne na temat stosunku Słowaków do ujawniania przypadków korupcji w miejscu pracy. Najbardziej znaczący wydaje się wniosek, że Słowacy coraz chętniej chcą zgłaszać korupcję. Przez ostatnie dwa lata wyraźnie wzrósł odsetek pozytywnych odpowiedzi na pytanie o gotowość do informowania o korupcji, którą to gotowość w 2017 roku deklarowało 40\% respondentów, podczas gdy jeszcze na początku 2015 roku było to $20 \%$, a w pierwszym roku realizacji sondażu, 2002, zaledwie 17\%. Trudno jednoznacznie wyjaśnić tak gwałtowną zmianę i udowodnić jakikolwiek jej związek z wprowadzeniem Ustawy 307/2014. Sugerowane wyjaśnienia odnoszą się do innych czynników, takich jak wzrost 
zaufania do słowackiej policji czy pojawienie się społecznej presji związanej m.in. ze sprawą Hlavkovej, aby otwarcie sprzeciwiać się korupcyjnym praktykom [People are more willing..., 2017]. Natomiast wyraźnie widać, że chęć do zgłaszania korupcji wzrasta u Słowaków wraz z zarobkami, a więc zabezpieczenie materialne na wypadek na przykład konieczności odejścia z pracy pomaga przełamywać bariery przed sygnalizowaniem. W porównaniu z 2016 rokiem, kiedy zaledwie $26 \%$ respondentów potwierdziło, że jest świadomych wprowadzenia w ich kraju nowego prawa chroniącego pracowników ujawniających korupcję przed zwolnieniem, w 2017 roku odsetek ten znacząco wzrósł, do 44\%.

Natomiast w świetle badań GCB z 2013 i 2016 roku najważniejsze bariery wymieniane przez Słowaków zniechęcające do raportowania korupcji w 2013 i 2016 pozostają niezmienne, czyli: obawa przed przykrymi konsekwencjami (40\% w 2013 i $27 \%$ w 2016) oraz przekonanie, że ich zgłoszenie nic nie zmieni (37\% w 2013 i 22\% w 2016). Jedynie 7\% Słowaków, najmniej w Unii Europejskiej, jest zdania, że raportowanie korupcji to najbardziej skuteczny sposób walki z nią (GCB, 2016). Ponadto zaledwie $21 \%$ Słowaków zgadza się ze stwierdzeniem, że zgłaszanie korupcji jest w ich kraju zachowaniem społecznie akceptowanym (GCB, 2016). Potwierdzają to też odpowiedzi na inne pytanie, w którym respondenci w zdecydowanej większości (40\%) odpowiedzieli, że będąc świadkami korupcji, osobiście nie czuliby się zobowiązani jej zgłosić (GCB, 2016).

Z przytaczanych już badań TI wynika, że 56\% Słowaków negatywnie ocenia działania słowackiego rządu w walce z korupcją (GCB, 2016). Premier Robert Fico zapowiedział już nowelizację Ustawy 307/2014, dzięki której ludzie przestaną bać się informować o przypadkach korupcji, postulując, żeby status sygnalistów był zbliżony do statusu świadka koronnego [PM calls to fight corruption..., 2017]. Jej projekt, wprowadzający nowe środki ochrony, jest obecnie w trakcie procesu legislacyjnego [LP/2018/109 Zákon o ochrane oznamovatelov...]. Według TIS, problem z obecną ustawą leży natomiast we wpływaniu na śledztwa zgłaszane przez sygnalistów przez wysokich funkcjonariuszy policji i polityków.

\section{Podsumowanie}

Słowacja przez długi czas była pozbawiona prawodawstwa dedykowanego sygnalistom. Istotnym czynnikiem przy jego uchwalaniu okazała się presja organizacji międzynarodowych oraz organizacji pozarządowych. Nowe prawo było prezentowane jako element polityki antykorupcyjnej słowackiego rządu, nie budziło jednak specjalnych społecznych emocji ani zainteresowania. Mimo że problem korupcji uznano za wyjątkowo nabrzmiały na Słowacji, środkiem do jego zwalczania, bardziej odpowiednim niż whistleblowing, w społecznym odczuciu nadal pozostaje zmiana funkcjonowania organów ścigania i wymiaru sprawiedliwości. Kryzys zaufania do aparatu państwa wydaje się najpoważniejszą barierą przed sygnalizowaniem i korzystaniem z przewidzianych prawem mechanizmów ochrony. Ponadto nie zadbano o kompetencyjne i finansowe 
wzmocnienie instytucji przyznającej sygnalistom ochronę przed działaniami odwetowymi, czyli inspekcji pracy. Wszystko to złożyło się na brak widocznych rezultatów Ustawy 307/2014 w pierwszym okresie jej funkcjonowania.

Niewątpliwie przewidziane w Ustawie 307/2014 mechanizmy ochrony tak prewencyjnej, jak i następczej pracowników zagrożonych działaniami odwetowymi za ujawnienie nieprawidłowości zasługują na uwagę jako procedury uwzględniające różne sytuacje, w których może znaleźć się sygnalista. Poważną zmianą jest też obowiązek wdrożenia wewnętrznych systemów zgłaszania nieprawidłowości, dotyczący zarówno sektora publicznego, jak i prywatnego.

Trudno jednak udowodnić hipotezę, że ustawowa ochrona sygnalistów pomogła zmniejszyć opory Słowaków związane z raportowaniem korupcji, tym bardziej że większość z nich, jak pokazały ostatnie badania, pozostaje nieświadoma istnienia Ustawy 307/2014. Wyniki przedstawionych sondaży wskazują, że z jednej strony opinie Słowaków ewoluują w stronę większej gotowości zgłaszania nieprawidłowości i zrozumienia dla tego rodzaju postaw. Z drugiej, mimo wzmocnienia sygnalistów i podniesienia ich praw do rangi osobnej ustawy, sceptycyzm wobec sensu zgłaszania nieprawidłowości w interesie publicznym na Słowacji pozostaje silniejszy aniżeli w większości krajów Unii Europejskiej.

\section{Bibliografia}

Are whistleblowers still more like stunts? (2014), http://www.nfpk.cz/en/news/3566 [dostęp: 23.07.2017].

Cenkner M. (2017), Hodnotiaca správa slovenského národného strediska pre ludské prava k problematike chráneného oznamovania v Slovenskej republike za rok 2016, Slovenské národné strediska pre ludské prava, Bratislava, http://www.snslp.sk/CCMS/ files/2Hodnotiaca_sprava_2016___finalna_verzia.pdf [dostęp: 28.10.2017].

Committing to Effective Whistleblower Protection (2016), OECD.

Country Review Report of Slovak Republic (2013), UNODC https://www.unodc.org/documents/treaties/UNCAC/CountryVisitFinalReports/2013_07_11_Slovakia_Final_Country_Report.pdf [dostęp: 26.07.2017].

Cuprik R. (2016), CROWS: Whistleblowers often pay big price for courage, „The Slovak Spectator", 1(22).

Cywilnoprawna Konwencja o Korupcji Rady Europy sporządzona w Strasburgu dnia 4 listopada $1999 \mathrm{r}$.

Dyrektywa wykonawcza Komisji (UE) 2015/2392 z dnia 17 grudnia 2015 r. w sprawie rozporządzenia Parlamentu Europejskiego i Rady (UE) nr 596/2014 w odniesieniu do zgłaszania właściwym organom rzeczywistych lub potencjalnych naruszeń tego rozporządzenia.

Dyrektywa Parlamentu Europejskiego i Rady (UE) 2015/849 z dnia 20 maja 2015 r. w sprawie zapobiegania wykorzystywaniu systemu finansowego do prania pieniędzy lub finansowania terroryzmu, zmieniająca rozporządzenie Parlamentu Europejskiego i Rady (UE) nr 648/2012 i uchylająca dyrektywę Parlamentu Europejskiego i Rady 2005/60/WE oraz dyrektywę Komisji 2006/70/WE. 
Dyrektywa Parlamentu Europejskiego i Rady (UE) 2016/943 z dnia 8 czerwca 2016 r. w sprawie ochrony niejawnego know-how i niejawnych informacji handlowych (tajemnic przedsiębiorstwa) przed ich bezprawnym pozyskiwaniem, wykorzystywaniem i ujawnieniem.

International Principles for Whistleblower Legislation (2013), Transparency International, https://issuu.com/transparencyinternational/docs/2013_whistleblowerprinciples_en [dostęp: 26.07.2017].

Konwencja Narodów Zjednoczonych Przeciwko Korupcji, przyjęta przez Zgromadzenie Ogólne Narodów Zjednoczonych dnia 31 października 2003 r.

Krošlák D., Olšovska A. (2015), Whistlebowing in the Slovak labour law regulation, „Juridical Tribune" 2(5).

LP/2018/109 Zákon o ochrane oznamovatel'ov a o zmene a doplnení niektorých zákonov, https:// www.slov-lex.sk/legislativne-procesy/-/SK/dokumenty/LP-2018-109 [dostęp: 20.03.2018]

Oznamovatel’ov korupcie chránime len na papieri. Plus tri prípadové štúdie zo zahraničia (2015), Transparency International Slovensko, Bratislava, http://www.snslp.sk/CCMS/ files/Oznamovate\%C4\%BEov_nekalej_\%C4\%8Dinnosti_chr\%C3\%A1nime_len_na_papieri_1_.pdf [dostęp: 12.02.2016].

Global Corruption Barometer 2016. Results for Europe and Central Asia (2016), Transparency International, https://www.transparency.org/news/feature/governments_are_doing_a_ poor_job_at_fighting_corruption_across_europe [dostęp: 26.07.2017].

People are more willing to report corruption (2017), https://spectator.sme.sk/c/20546028/people-are-more-willing-to-report-corruption.html?ref=av-center [dostęp: 13.08.2017].

PM calls to fight corruption (2017), https://spectator.sme.sk/c/20546540/pm-calls-to-fightcorruption.html [dostęp: 13.08.2017].

Prieskum verejnej mienky. Záverečná správa z kvantitatívneho prieskumu pre Transparency International Slovensko (2016), FOCUS na zlecenie Transparency International Slovensko, Bratysława, http://www.transparency.sk/wp-content/uploads/2016/06/FOCUS-Sprava_TIS_maj2016.pdf [dostęp: 31.07.2017].

Prieskum verejnej mienky. Záverečná správa z kvantitatívneho prieskumu pre Transparency International Slovensko (2017), FOCUS na zlecenie Transparency International Slovensko, Bratysława, http://transparency.sk/sk/korupcia-nahlasit-whistleblowing/ [dostęp: 13.08.2017].

Protection of whistleblowers. Recommendation CM/Rec (2014)7 of the Committee of Ministers of the Council of Europe on 30 April 2014 and explanatory memorandum (2014), Rada Europy, https://rm.coe.int/16807096c7 [dostęp: 26.07.2017].

Providing an alternative to silence: towards greater protection and support for whistleblowers in the EU. Country Report: Slovak Republic (2012), Transparency International, Bratislava.

Rédli E. (2015), Whistleblower law is weak in practice, „The Slovak Spectator” 21(25).

Rekomendacje Rady OECD w sprawie dalszego zwalczania przekupstwa zagranicznych funkcjonariuszy publicznych w międzynarodowych transakcjach handlowych z dnia 26 listopada $2009 \mathrm{r}$.

Rezolucja Parlamentu Europejskiego z dnia 14 lutego 2017 r. Rola demaskatorów w ochronie interesów finansowych UE (2016/2055(INI)).

Rezolucja Parlamentu Europejskiego z dnia 24 października 2017 r. w sprawie uzasadnionych środków ochrony sygnalistów działających $\mathrm{w}$ interesie publicznym podczas 
ujawniania poufnych informacji posiadanych przez przedsiębiorstwa i organy publiczne (2016/2224(INI)).

Slovak Republic: Follow-up to the phase 3 report \& recommendations (2014), OECD, http:// www.oecd.org/daf/anti-bribery/Slovak-Republic-Phase-3-Written-Follow-up-Report-EN. pdf [dostęp: 14.08.2017].

Slovakia Corruption Report (2015), GAN Integrity, www.business-anti-corruption.com/country-profiles/slovakia [dostęp: 4.03.2017].

Special Eurobarometer 374: Corruption (2012), Report, https://data.europa.eu/euodp/pl/data/ dataset/S1010_76_1_EBS374 [dostęp: 14.08.2017].

Special Eurobarometer 397: Corruption (2014), Report, https://data.europa.eu/euodp/en/data/ dataset/S1076_79_1_397 [dostęp: 26.07.2017].

Terenzani M. (2016), Smer links alleged behind Evka, „The Slovak Spectator” 22(24).

The EU Anti-Corruption Report. Annex 25 Slovakia (2014), European Commission, Brussels.

The Global Corruption Barometer 2013 survey. Summary of results Slovakia (2013), Transparency International.

Výročná správa 2016 (2016), Centrum právnej pomocy, http://www.centrumpravnejpomoci.sk/wp-content/uploads/2014/03/V\%C3\%BDro\%C4\%8Dn\%C3\%A1-spr\%C3\%A1va2016-FINAL.pdf [dostęp: 28.10.2017].

Waszak M. (2016), Zwiąki zawodowe i organizacje pracodawców a ustawy o ochronie sygnalistów. Przykłady europejskie [w:] G. Makowski, M. Waszak (red.), Sygnaliści w Polsce okiem pracodawców i związów zawodowych, Fundacja im. Stefana Batorego, Warszawa, http://www.batory.org.pl/upload/files/Programy\%20operacyjne/Odpowiedzialne\%20 Panstwo/Sygnalisci-w-Polsce-okiem-pracodawcow-i-zwiazkow-zawodowych.pdf [dostęp: 26.07.2017].

Whistleblowing in Europe. Legal protection for whistleblowers in the EU (2013), Transparency International, https:/www.transparency.org/whatwedo/publication/whistleblowing in_europe_legal_protections_for_whistleblowers_in_the_eu [dostęp: 26.06.2017].

Zakon zo 16. oktobra 2014 o niektórych opatreniach súvisiacich z oznamovanim protispoločenskej činnosti a o zmene a doplneni niektorých zákonov. 